\title{
Annotations
}

\section{Supplementary vitamin D in infancy and childhood}

Rickets is the only important vitamin deficiency disease in Britain and as such demands regular review. In children and infants outside the neonatal period the problem is occasional, sporadic, mainly urban, and predominantly, though not exclusively, northern in distribution. These general features have changed little during the past generation, but recent interest has been directed towards vitamin $\mathbf{D}$ deficiency in vulnerable minority groups and in neonates, particularly those born preterm.

\section{Vitamin D supplements in term infants and older children}

There is no evidence that breast or formula fed term infants who are weaned at the normal time to a normal British diet ever get nutritional rickets and the sporadic cases seen in every paediatric department nearly always have some social or nutritional peculiarity. There have been occasional reports of exclusively breast fed term infants, mainly in poor black families in the USA, who have developed rickets. ${ }^{1-3}$ The amount of dietary vitamin $D$ needed by the normal infant is probably very small, since breast milk is a poor source. ${ }^{4}$ Reports of the presence of ample quantities of water soluble cholecalciferol sulphate in human milk ${ }^{5}$ are now in doubt, ${ }^{46}$ and the water soluble fraction has not been shown to have antirachitic properties. ${ }^{4}$ A recent paper from Cincinnati $^{8}$ however, showed in a double blind prospective study that bone mineral content increased in breast fed babies given vitamin $\mathbf{D}$ supplements in comparison with unsupplemented controls. The importance of this small study in relation to the development of rickets is not clear and a subsequent study, ${ }^{9}$ larger but not blind, did not confirm the findings. From the available evidence it is very unlikely that the average breast fed British infant needs supplementary vitamin $D$ and formula fed infants receive it in the preparation.

There are infants and children in Britian who are at risk of vitamin $\mathrm{D}$ deficiency and most prominent among these are the children of Asians from India, Pakistan, Bangladesh, and East Africa. Intrauterine vitamin $\mathbf{D}$ deficiency is common among these peoples, ${ }^{1011}$ and may leave a legacy of poor growth in infancy unless supplements are given. ${ }^{12}$ Rickets occurring during puberty is also well known in Asians. ${ }^{13}$ Other infants at risk are those brought up in families that eat a macrobiotic $\operatorname{diet}^{14}{ }^{15}$ or that are I-tal vegetarians (largely Rastafarian) ${ }^{16}$ and children on prolonged anticonvulsant treatment with phenytoin or phenobarbitone. ${ }^{17}$

\section{Recommendations for term infants and older children}

Special groups will remain at risk and need supplements. The difficulty is that with the exception of Asians and children on anticonvulsants, the infants at risk are often hard to identify and their parents may well refuse to give them anything not considered 'natural'. The problem of the urban underprivileged poor remains, however, and there are sporadic cases of rickets in families who have no special dietary practices or beliefs. It is probable that these cases could be prevented with vitamin D supplements in infancy. Therefore, in view of the absence of toxicity of vitamin $\mathrm{D}$ given at a dose of $400 \mathrm{U} /$ day, ${ }^{18}$ it seems wise to continue with the general recommendation that all breast fed infants should be given this level of supplementation and that bottle fed infants should be given one of the adapted formulas (supplemented with vitamin D) until they are at least 6 months old. All Asian infants should be given vitamin D supplements whether breast or bottle fed. Children on anticonvulsants should have their alkaline phosphatase activity monitored at regular intervals and be given supplements if indicated.

\section{Preterm infants}

Rickets is common in preterm infants of very low birthweight ${ }^{19-21}$ even with adequate vitamin D supplementation, normal or high serum 25hydroxycholecalciferol (OHD) concentrations, and apparently normal or high serum 1,25-dihydroxycholecalciferol $\left((\mathrm{OH})_{2} \mathrm{D}\right)$ concentrations. ${ }^{21-23}$ Recent years have seen an explosion of published work on this subject, but the pathogenesis of preterm rickets is still uncertain and since the disorder may be severe enough to cause spontaneous fractures and respiratory difficulties, ${ }^{24} \mathbf{2 5}$ it cannot be ignored. Vitamin D supplements are certainly needed by preterm infants, but we do not know at present how much, or in what form. Calcium deficiency ${ }^{26}{ }^{27}$ and phosphorus deficiency ${ }^{28}$ have also been implicated and inadequate provision of these substrates, particularely in the infant of $<1500 \mathrm{~g}$ in weight fed breast milk, may be an important factor in rickets. 
Hydroxylation of vitamin D seems adequate both in liver and kidney ${ }^{21-23} 29$ and the preterm gut is responsive to $1,25(\mathrm{OH})_{2} \mathrm{D} .{ }^{29} \mathrm{~A}$ daily intake of at least $1000 \mathrm{IU}$ and possibly $2000 \mathrm{IU}$ of vitamin D as calciferol may be required for maximal calcium absorption, ${ }^{29}$ and even then rickets may still occur. ${ }^{21}$ In these circumstances plasma calcium and urinary calcium excretion will give a guide to the adequacy of the calcium and phosphorus intake. ${ }^{30}$ These minerals should be supplemented as necessary, ensuring that the dietary $\mathrm{Ca} / \mathrm{P}$ ratio does not fall below 1.5 or rise above $2 \cdot 2$. So long as adequate substrate is provided rickets in preterm infants will heal with time as gut absorption mechanisms mature. If the infant is ill as a result of rickets, however, healing may be more rapid if alphacalcidol is given $^{31}(0 \cdot 1-0 \cdot 2 \mu \mathrm{g} / \mathrm{kg}$ daily $)$, and this is the practice in our unit. There is no evidence that the routine administration of alphacalcidol to preterm infants is necessary or desirable.

\section{Available preparations}

Vitamin D is available as calciferol solution $(3000$ $\mathrm{U} / \mathrm{ml}$ ) suitable for supplementing the diet of preterm infants. Most clinicians will want to give other vitamins as well, so these infants may also receive additional vitamin $\mathbf{D}$ in a commercial multivitamin preparation such as Abidec (Parke-Davis) or Concavit (Wallace). A daily dose of $0.6 \mathrm{ml}$ Abidec will provide $400 \mathrm{U}$ vitamin $\mathrm{D}$. Alphacalcidol is available as One-Alpha (Leo).

\section{References}

1 Arnaud S D, Stickler G B, Haworth J C. Serum 25-hydroxyvitamin D in infantile rickets. Pediatrics 1976; 57: 221-5.

2 O'Connor P. Vitamin D-deficiency rickets in two breastfed infants who were not receiving vitamin D supplementation. Clin Pediatr 1977; 16: 361-3.

3 Bachrach S, Fisher J, Parks J S. An outbreak of vitamin $D$ deficiency rickets in a susceptible population. Pediatrics 1979; 64: 871-7.

4 Leerbeck E, Søndergaard H. The total content of vitamin D in human milk and cows' milk. Br J Nutr 1980; 44: 7-12.

5 Lakdawala D R, Widdowson E M. Vitamin-D in human milk. Lancet 1977; i: 167-8.

- Brown I R F. Letter: Water-soluble vitamin D in human milk. Arch Dis Child 1982; 57: 81.

7 Reeve L E, De Luca H F, Schnoes H K. Synthesis and biological activity of vitamin D 3-sulfate. J Biol Chem 1981; 256: 823-6.

8 Greer F R, Searcy J E, Levin R S, Steichen J J, Asch P S, Tsang $R$ C. Bone mineral content and serum 25-hydroxyvitamin $\mathrm{D}$ concentration in breast-fed infants with and without supplemental vitamin D. J Pediatr 1981; 98: 696-701.

9 Roberts C C, Chan G M, Folland D, Rayburn C, Jackson $R$. Adequate bone mineralization in breast-fed infants. $J$ Pediatr 1981 ; 99: 192-6.

10 Brooke O G, Brown I R F, Bone C D M, et al. Vitamin D supplements in pregnant Asian women: effects on calcium status and fetal growth. Br Med J 1980; 280: 751-4.
11 Brooke O G, Brown I R F, Cleeve H J W, Sood A. Observations on the vitamin D state of pregnant Asian women in London. Br J Obstet Gynaecol 1981; 88: 18-26.

12 Brooke O G, Butters F, Wood C. Intrauterine vitamin D nutrition and postnatal growth in Asian infants. Br Med J 1981; 283: 1024.

13 Cooke W T, Asquith P, Ruck N, Melikian V, Swan C H J. Rickets, growth, and alkaline phosphatase in urban adolescents. $\mathrm{Br}$ Med J 1974; ii: 293-7.

14 Dwyer J T, Dietz W H, Jr, Hass G, Suskind R. Risk of nutritional rickets among vegetarian children. Am J Dis Child 1979; 133: 134-40.

15 Roberts I R F, West R J, Ogilvie D, Dillon M J. Malnutrition in infants receiving cult diets: a form of child abuse. Br Med J 1979; i: 296-8.

16 Ward P S, Drakeford J P, Milton J, James J A. Nutritional rickets in Rastafarian children. $\mathrm{Br}$ Med $\mathrm{J}$ 1982; 285 : 1242-3.

17 Lifshitz F, Maclaren N K. Vitamin D-dependent rickets in institutionalized mentally retarded children receiving long-term anticonvulsant therapy. 1. A survey of 288 patients. $J$ Pediatr 1973; 83: 612-20.

18 Finberg L. Human milk feeding and vitamin D supplementation-1981. J Pediatr 1981; 99 : 228-9.

19 Kulkarni P B, Hall R T, Rhodes P G. Rickets in very low-birth-weight infants. J Pediatr 1980; 96: 249-52.

20 Callenbach J C, Sheehan M B, Abramson S J, Hall R T. Etiologic factors in rickets of very low-birth-weightinfants. $J$ Pediatr 1981; 98: 800-5.

21 McIntosh N, Livesey A, Brooke O G. Plasma 25-hydroxyvitamin $D$ and rickets in infants of extremely low-birthweight. Arch Dis Child 1982; 57: 848-51.

22 Chesney R W, Hamstra A J, De Luca H F. Rickets of prematurity. Supranormal levels of serum 1, 25-dihydroxyvitamin D. Am J Dis Child 1981; 135: 34-7.

${ }^{23}$ Steichen J J, Tsang R C, Greer F R, Ho M, Hug G. Elevated serum 1, 25-dihydroxyvitamin $D$ concentrations in rickets of very low-birth-weight infants. $J$ Pediatr 1981 ; 99: 293-8.

24 Geggel R L, Pereira G R, Spackman T J. Fractured ribs: unusual presentation of rickets in premature infants. J Pediatr 1978; 93: 680-2.

25 Glasgow J F T, Thomas P S. Rachitic respiratory distress in small preterm infants. Arch Dis Child 1977; 52: 268-73.

26 Von Sydow C. A study of the developments of rickets in premature infants. Acta Paediatr Scand [Suppl] 1946; 33: Supplement 2, 1-122.

27 Day G M, Chance G W, Radde I C, Reilly B J, Park E, Sheepers J. Growth and mineral metabolism in very lowbirth-weight infants. II. Effects of calcium supplementation on growth and divalent cations. Pediatr Res 1975; 9: $568-75$.

28 Rowe J C, Wood D H, Rowe D W, Raisz L G. Nutritional hypophosphatemic rickets in a premature infant fed breast milk. $N$ Engl J Med 1979; 300: 293-6.

29 Senterre J, Salle B. Calcium and phosphorus economy of the preterm infant and its interaction with vitamin $D$ and its metabolites. Acta Paediatr Scand [Suppl] 1982; Supplement 296, 85-92.

30 Brooke $O \mathrm{G}$. Low birthweight babies: nutrition and feeding. Br J Hosp Med 1982; 28: 462-9.

31 Seino Y, Ishii T, Shimotsuji T, Ishida M, Yabuuchi $\mathbf{H}$. Plasma active vitamin $D$ concentration in low birthweight infants with rickets and its response to vitamin D treatment. Arch Dis Child 1981; 56: 628-32.

O G BROOKE

Department of Child Health, St George's Hospital Medical School, Cranmer Terrace, London SW17 ORE 